\title{
The Role of non-Western Countries in the Construction of Russian Great Powerness: The Cases of Turkey and Israel
}

\author{
Ebru Birinci $^{1} \bowtie$, Ali E. Sucu ${ }^{(}$, Ivan A. Safranchuk ${ }^{2}$ \\ ${ }^{1}$ Lomonosov Moscow State University, Moscow, Russian Federation \\ ${ }^{2}$ MGIMO University, Moscow, Russian Federation \\ \ebrubirinci@windowslive.com
}

\begin{abstract}
This article contributes to the study of Russian great powerness, focusing on the potential of the Russian-Turkish and Russian-Israeli relations to influence the construction of Russia's great power status in a multipolar world. Based upon Russian and English literature dedicated to the study of great power concept and Russian great powerness, authors adopt analytic eclecticism for the theoretical framework of the study. In this regard, for a comprehensive understanding of Russian great powerness, both constructivism with its focus on identity, and neorealism stressing national interests, security, and power, are applied. The authors actively employ the official documents, international agreements, statements of government officials, and official declarations. As a result, the study examines to what extent bilateral relations with Turkey and Israel, the West's traditional nonWestern allies, can contribute to the construction of Russian great power identity. For this purpose, first of all, the factors of Russian great power construction and its role in Russian foreign policy are examined. After addressing the efficiency of great power status as a foreign policy tool, the development of Russian-Turkish and Russian-Israeli relations are discussed. It is concluded that Russia has developed strategically significant relations with Turkey and Israel despite the deteriorated relations with the West, and the development of these relations has supported the consolidation of Russia's great power status at the international and regional levels. Furthermore, the study suggests that Russian-Turkish and Russian-Israeli bilateral relations can enable Russia to strengthen its great power status vis-à-vis the West via cooperation and competition and contribute to the construction of a multipolar world.

Key words: great powerness, Russian-Turkish relations, Russian-Israeli relations, foreign policy, identity, Russian foreign policy, the West

For citation: Birinci, E., Sucu, A. E., \& Safranchuk, I. A. (2021). The Role of non-Western Countries in the Construction of Russian Great Powerness: The Cases of Turkey and Israel. Vestnik RUDN. International Relations, 21(3), 517-528. https://doi.org/10.22363/2313-0660-2021-21-3-517-528
\end{abstract}

\section{Роль незападных стран в формировании российской великодержавности: примеры Турции и Израиля}

\author{
Э. Биринчи $1 \square$, А.Э. Суджу \\ ${ }^{1}$ Московский государственный университет имени М.В. Ломоносова, Москва, Российская Федерация \\ ${ }^{2}$ МГИМО Университет, Москва, Российская Федерация \\ \ebrubirinci@windowslive.com
}

Аннотация. В статье рассматривается великодержавность России в контексте влияния динамики российско-турецких и российско-израильских отношений на формирование великодержавного статуса России в многополярном мире. Опираясь на исследования на английском и русском языках, посвященные

(C) Birinci E., Sucu A.E., Safranchuk I.A., 2021

This work is licensed under a Creative Commons Attribution 4.0 International License.

https://creativecommons.org/licenses/by/4.0/ 
изучению концепций великой державы и российской великодержавности, авторы прибегают к аналитическому эклектизму в качестве теоретической основы исследования. Для изучения великодержавности России используются конструктивизм с опорой на базовый концепт идентичности, а также неореализм с неизменным приоритетом национальных интересов, безопасности и государственной мощи. На основе представленных теоретических подходов анализируются официальные документы, международные соглашения, заявления государственных должностных лиц и официальные декларации. Изучается вопрос, в какой степени двусторонние отношения России с Турцией и Израилем, являющимися традиционными незападными союзниками стран Запада, могут способствовать формированию российской идентичности великой державы. Для этого исследуются факторы формирования российской великодержавности и ее роль в российской внешней политике. После анализа статуса великой державы как инструмента российской внешней политики изучается развитие российско-турецких и российско-израильских отношений. Авторы приходят к выводу, что Россия развивает стратегические отношения с Турцией и Израилем, несмотря на ухудшение отношений с Западом. Это способствует укреплению статуса России как великой державы на международном и региональном уровнях. Кроме того, выдвигается тезис, что развитие российско-турецких и российскоизраильских отношений может укрепить великодержавный статус России в отношениях со странами Запада и внести вклад в формирование многополярного мира.

Ключевые слова: великодержавность, российско-турецкие отношения, российско-израильские отношения, идентичность, российская внешняя политика, Запад

Для цитирования: Birinci E., Sucu A.E., Safranchuk I.A. The Role of non-Western Countries in the Construction of Russian Great Powerness: The Cases of Turkey and Israel // Вестник Российского университета дружбы народов. Серия: Международные отношения. 2021. Т. 21. № 3. С. 517-528. DOI: 10.22363/2313-0660-2021$21-3-517-528$

\section{Introduction}

Russia's great power status is an extensive concept that should be comprehended in terms of both material and ideational parameters. On the one hand, Russian political discourse attributes Russian great powerness to material sources such as vast Russian territory, Russian military and nuclear power. On the other hand, great powerness is an element of Russian national identity as a historical continuity, evolving with Russia's belonging to and exclusion from the West. Despite the efforts to integrate Russia to the western world after the collapse of Soviet Union, self-other nexus determined the nature of Russian-Western relation. Against the backdrop of deteriorated Russian-Western relations since 2014 and China's rise as a potential superpower Russia has turned to the East and China to avoid its political and economic isolation. Nevertheless, securing Russian great power status, which is possible in a multipolar world system, requires Russia to maintain better relations with the West, and prevent a total the US-Chinese (bi)polarisation of the world order.

Despite the plenitude of scholarly work addressing Russian great power status and its construction within the framework of its relations with the West, no particular study has paid specific attention to what extent Russian great power status considerations are prominent and instrumental beyond the Western direction.

Turkey and Israel constitute suitable directions for contributing the study of Russian great powerness beyond the Western direction, as they are Western-oriented non-western countries, that Russia's relations cannot simply be understood as a pro-Western or anti-Western. In spite of deteriorated relations with the West, Russia could maintain pragmatic relations with the traditionally Western allies such as Turkey and Israel in the Middle East, where it has strengthened its great power status through military and diplomatic achievements. In the light of this picture, Russia obtains the opportunity to employ its relations with Turkey and Israel, it developed under Vladimir Putin's presidency, as a leverage in its relations with the West and to enhance its great power role in a multipolar world order.

\section{Construction of Russian Great Powerness as Historical Continuity}

Great powerness is a concept in international relations (IR), can be understood both by material and ideational categories (Buzan \& Waever, 2004, p. 32). The large scale 
of these categories and the alternative interpretations of individual IR theories prevented a general agreement on the parameters by which a country should be classified as a great power (Shakleina, 2011, p. 30). When assessing the great power status of a country, the neoliberal theory gives the first place to the economic power, levels of economic dependencies with other states, the share in the world economy, the standard of living of citizens, scientific, technical potential capabilities and participation of the state in international and regional institutions. The neorealist theory, for its part, takes into consideration the measurable resources such as military power, territory, population, natural resources, development of societies, geopolitical interests of states, foreign policy alliances, etc. From a neorealist point of view, it is also significant that the great power status of a country should be recognized by other actors based on the status and influence on weaker states in the international system (Mearsheimer, 2001). Furthermore, the criteria of determining the great power status of any state depend on the systemic structure of the international system as bipolar, unipolar or multipolar. For instance, in unipolar and bipolar systems, states with great power capacity have limited foreign policy areas for emerging great power states. In a multipolar international system, on the contrary, states have the opportunity to strengthen their great power roles through a balance of power. Therefore, the international system directly affects the status behaviors of the actors.

There are two aspects of defining Russia as a great power in the international system. The first is to what extent Russia is recognized as a great power based on its material capabilities by the major actors in the system, and the other is the constructing Russian great powerness as a core of national identity and foreign policy concept. Hence, Russia's great power status is suitable to discuss and comprehend both material and ideational sources of great powerness. According to A. P. Tsygankov, Russian great powerness implies "(1) a sphere of cultural and value influence in Eurasia and Europe, (2) political and economic self-sufficiency, and
(3) military capabilities sufficient to defeat any other power" (Tsygankov, 2020). Russia's great power assertion relies on its material and behavioral capabilities. Its military power, natural resources, vast territory, scientifictechnological development, and size of its economy are sufficient to assume the great power status today. In addition to tangible material resources, Russia is an influential state in international and regional institutions that support this status in the international system with its permanent membership in the UN Security Council, its involvement in regional and global non-Western alliances such as SCO, AEB, and BRICS, and its influence on regional and global developments.

On the other hand, status considerations are influential as much as material resources for great powerness in the constructivist studies, focusing on identity for a better understanding of states' foreign policies. The predominance of the West in the formation of Russian identity, Russian orientation towards the West in the course of modern history is a phenomenon, to development of which many scholarly works contributed mainly since the introduction of constructivist theory into the international relations studies (Neumann, 2003; Hopf, 2002). The perceptual source of such an approach to the Russian great powerness dates back to Peter the Great's reforms inspired by the Western values (Safranchuk, 2020).

Sergei Karaganov emphasizes that sovereignty and defense are Russian national ideas, and Russia has been feeling more and more like a great power since the time of Peter the Great ${ }^{1}$. Institutionalization of Russian statehood in a historical continuity began within the European-state system at the end of the Eighteenth Century. Russian Empire was an equal (European) great power of the Concert of Europe in the 19th century, a multipolar international order limited to Europe, where a balance of great powers could be preserved for a

\footnotetext{
${ }^{1}$ Караганов С.А. Чтобы выживать, Россия должна побеждать // Россия в глобальной политике. 20.11.2017. URL: https://globalaffairs.ru/articles/chtobyvyzhivat-rossiya-dolzhna-pobezhdat/ (дата обращения: 15.01.2020).
} 
few decades. Under the bipolar world order during the Cold War, on the other hand, the USSR, Russian Federation's predecessor, acted as one of the two superpowers with the military, economic, political capacities, and ideological cause. Unlike Tsarist Russia, the Soviet Union built an anti-western / anti-capitalist Soviet identity.

The demise of the USSR, which already started to adopt liberal western values, brought an identity crisis to Russia. During the 1990s, pro-Western and anti-Western groups conflicted over the place to which Russia belonged. In the early 1990s, when the Westernizers, such as Andrei Kozyrev, Yegor Gaidar, acquired significant positions in the government, Russian foreign policy oriented in the West, Russia did not oppose the US policies, hoping to become a full member of the Western civilization (Kuchins \& Zevelev, 2012, p. 149; Safranchuk, 2018, pp. 98-99). The Statist idea, supporting a stronger state and revival of Russia's great power status, has gradually found more support among political elites against the backdrop of NATO's continuing expansion towards Eastern Europe and rising domestic discontent with the advantages of the tardy integration with the West (Tsygankov, 2016, p. 68). Yevgeny Primakov, who later served as minister of foreign affairs and prime minister, led the statist camp in Moscow. He was a politically exposed person in the Middle East and represented the USSR in secret meetings with Israel between 1971 and 1977. Primakov's appointment as the minister of foreign affairs in 1996 marked the departure from the Westernist policies with the well-known 'the Primakov Doctrine' and restoration of relations with the Eastern powers. According to the statist view, NATO's expansion in the former Soviet territories stemmed from the lack of Western recognition of Russian national interests and posed a threat to Russian sovereignty.

Russian President Vladimir Putin's foreign policy thinking has been a continuation of Primakov's conception. Consolidating Russia's place as a sovereign great power in a multipolar world has been Putin's foreign policy objective since he acceded to power in 2000. Nevertheless, the international terrorism and the other expanding global problems that call international cooperation with the West, rendered Putin's foreign policy understanding more pragmatic than that of Primakov.

Putin's realism evolved two-fold. First, Russia is dedicated to present itself as a great power, entitled to defend its national interests, constructed on the Tsarist and Soviet experiences, against the western expansionism in and out of the former Soviet territories. Second, distinguishing the US from the West in general, it acknowledges the superiority of American power. Furthermore, Russia officially values the international institutions' role, the need for global cooperation to cope with global problems.

Since Putin's Munich speech (2007), Russian criticism over the US/NATO unilateralist policies intensified, and RussianWestern tension increased. The Ukrainian crisis in 2014 has been the turning point of RussianWestern relations. The West imposed sanctions on Russia, Russia has been excluded from G-7, insulated from the Western(-centric) world. In the face of these developments, Russia conducted a military operation in Syria in 2015 and developed its relations with non-Western countries, particularly China. The current Russian foreign policy tilt to Asia and the deteriorated relations with the West should not be interpreted as a departure from the Westernoriented (Eurocentric) foreign policy thinking. It is an exclusionary moment in the RussianWestern relations. In the historical context, Russian foreign policy thinking, in parallel with the Russian identity, evolved under the effect of its relations with the West, more precisely, its exclusion from and inclusion / belonging to Europe.

By the 2010s, on the one hand, the US global hegemony gradually decreased, Brexit endangered the European cooperation, Trump's election as the US president encouraged nationalist and popular ideas, on the other hand, China has risen as an economic superpower, other middle and great powers succeeded more leverage. Such an international environment resembled a relative multipolar moment where Russia can also assume a great power role. After the Ukrainian crisis, Russia could consolidate its 
great power status eliminating the further NATO expansion towards its borders. By confronting what it calls Western-backed forced regime change in Syria; it emerged as an assertive great power in the Middle East that can fill the void resulting from the diminishing US presence. These foreign policy achievements vis-à-vis the West became possible when Russia stopped appealing only to the West and enlarged cooperation with non-Western partners ${ }^{2}$. Russian international vision put a lot of emphasis to the global role of non-Western international organizations, SCO and BRICS in the first place, as key elements of the just world order, and also to the increasing role of regional organizations for solving security and economic challenges (Denisov \& Safranchuk, 2016; Lukin, 2018; Denisov et al., 2019).

Despite the tendency towards non-Western partners, Russian global economic, political, and ecological foreign policy objectives cannot be accomplished through its isolation from the Western world, given that Russia is economically and politically attached to Europe. Only the European Union (EU) itself is Russia's largest trade partner and Western countries and their allies continue to dominate the global economy. Furthermore, the most effective mechanisms and institutions tackling global problems from climate change to migration and terrorism, critical for Russia's security as much as other countries are built over the western neoliberal values. Lastly, Democrat candidate Joe Biden's election as the US president in 2020 signals a new assertiveness in the U.S. policy regarding these problems. Renascent global ambitions of the U.S., reminding pre-Trump period, stimulate the confrontation between Russia and the West. Therefore Russia, having economic and demographic constraints, rather than confronting the West, can use its diplomatic and military achievements in and beyond the post-Soviet territories to sustain ties with the

\footnotetext{
${ }^{2}$ Karaganov S.A. Where to go and with whom to go: Russia's foreign policy on the threshold of a new decade // Russia in Global Affairs. January 28, 2020. URL: https://eng.globalaffairs.ru/articles/where-to-go-and-withwhom-to-go-russias-foreign-policy-on-the-threshold-of-anew-decade/ (accessed: 21.05.2020).
}

West to address Russian foreign policy goals. In addition, Russia can use its "competitive advantages in the domain of indirect warfare" 3 through these relations drawing Russian-Western confrontation to the Western sphere of influence from the Russian sphere of influence. Developing bilateral relations with the traditional Western allies like Israel and Turkey since the end of the Cold War delivers Russia an opportunity this purpose. Through its relations with Turkey and Israel, Russia can strengthen its image as an equal great power, able to offer alternatives for the Western allies and create opportunities for enhancing cooperation with the Western powers.

\section{Russian-Turkish Relations}

Pro-Western orientation in Turkish foreign policy was one of the most significant elements that shaped Turkish-Soviet relations during the Cold War period. Therefore, in that period, Turkish-Russian relations were shaped by the perception of threat / security in general. Despite this perception, Turkish-Russian relations have begun to develop in the energy sphere with the construction of the first gas pipeline project in 1987 (Ulçenko, 2016, p. 122).

After the end of the Cold War, the disappearance of the land border between Turkey and Russia (by Georgia's and Armenia's independence) eliminated Turkey's security concerns from the Soviet Union. Besides, new republics that have gained independence in the South Caucasus and Central Asia have become a priority in Turkish foreign policy over time. As a result, a new competitive environment has emerged with Russia over these regions. Although the two states' foreign policy interests were always different from each other at the regional level, there was no de facto confrontation between Russia and Turkey during the 1990s, including the Azerbaijan - Armenia conflict. On the other hand, during this period, while both states tried to ensure economic and

\footnotetext{
${ }^{3}$ Kofman M. Great Power Competition in the 21st Century // Valdai Discussion Club. June 21, 2018. URL: https://valdaiclub.com/a/valdai-papers/great-powercompetition-in-21st-century/ (accessed: 21.05.2021).
} 
political stability within their countries. Turkey's PKK problem and the Russian Chechen problem forced both of them primarily to protect their territorial integrity.

Since the beginning of the 2000 s, due to the change of the governments and relatively stable economic growth in both countries, RussianTurkish relations have begun to develop in many areas from energy to military-security fields. Turkey is a member state of NATO; it generally followed pro-Western foreign policy discourse until the mid-2010s. However, currently, Turkey has started to move away from its goal of becoming a member of the European Union, and it is also experiencing a number of problems with NATO member states. Turkish foreign policy priorities are mainly differentiated from its western partners in Syria, Libya, the South Caucasus, and the Mediterranean Sea. At that point, Russia is emerging as a strategic partner for Turkey even though there is generally a conflict of interests of two states on a regional level. The Astana talks between Turkey, Iran and Russia, the bilateral cooperation mechanisms in Libya, and finally the creating military mechanism to control the ceasefire between Azerbaijan and Armenia, indicate that Turkey and Russia are acting jointly in solving regional crises. It can be said that bilateral relations have been progressing on the axis of cooperation in recent periods.

It is clear that Turkish policymakers aim to reformulate the foreign policy priorities of Turkey from the Western to the non-Western / Eurasian world. Russia, as a defender of the multilateral world order and pursuing a foreign policy for the restoration of its status as a great power on the regional level, aims to cooperate with Turkey to resolve regional problems. It gives both of them a significant opportunity to request to changes in the current international system.

\section{Political, Economic and Military Relations}

The structure of Turkish-Russian relations has several problems in itself. While Turkey and Russia's foreign policy interests in a global sense align with each other, conflicts of interest arising at the regional level pose some difficulties in defining the relations of the two countries. For instance, on the one hand, Turkish-Russian relations are defined as a strategic or multilateral partnership. On the other, since the 2000s, geopolitically breaking points have resulted in some crises in Turkish-Russian relations. For example, conflict in the Caucasus in 2008, the annexation of Crimea to Russia in 2014, and the November crises in 2015 have affected the structure of bilateral relations in such kind of dilemma from strategic partnership to regional rivalry. Lastly, the SU-24 jet crisis in 2015 results led to the fact that bilateral relations between Russia and Turkey returned from a strategic partnership to the process of "normalization" (Erşen, 2017, p. 95). These ups and downs raise the dilemma of "trust in distrust" in bilateral relations.

Turkish-Russian economic relations have started to develop steadily since the 1990s. Bilateral relations in the energy field constitute the most significant dimension of economic relations. Russia is the most significant state in Turkey's energy supply. Nowadays, it supplies gas to Turkey through only three pipelines: the Trans-Balkan Pipeline (1987), the Blue Stream Pipeline (2005), and the Turkish Stream Pipeline (2020). Finally, nuclear energy represents a new dimension of the energy relations between Russia and Turkey. The agreement on the construction of the Akkuyu nuclear power plant in the Turkish city of Mersin was signed in 2010, the project cost is estimated about 20 billion $\mathrm{USD}^{4}$. As cooperation in the energy sector continues to deepen, it should be noted that the discovered natural gas reserves by Turkey in the Black Sea can shape bilateral energy relations with Russia in coming years.

At the same time, Turkey is trying to diversify its energy supply countries. For instance, while apart from Russia, Turkey also imports natural gas from Azerbaijan, Iran and Algeria; it imports oil from Iraq, Russia, and Nigeria. According to statistics, in the list of Russian oil and petroleum products export countries, Turkey ranked 11th in 2013-2018 its total amount is 34.3 billion USD, and Turkey's

\footnotetext{
${ }^{4}$ Akkuyu NGS İnşaat Projesi // Akkuyu Nükleer. URL: http://www.akkunpp.com (accessed: 20.05.2021).
} 
Foreign Trade of Turkey and Russia, 2008-2019

\begin{tabular}{|c|c|c|c|c|c|c|c|}
\hline Russia & $\begin{array}{c}\text { Export to } \\
\text { Turkey, billion } \\
\text { USD }\end{array}$ & $\begin{array}{c}\text { Import from } \\
\text { Turkey, billion } \\
\text { USD }\end{array}$ & $\begin{array}{c}\text { Bilateral trade } \\
\text { volume, billion } \\
\text { USD }\end{array}$ & $\begin{array}{c}\text { Russia's } \\
\text { foreign trade, } \\
\text { billion USD }\end{array}$ & $\begin{array}{c}\text { Turkey's } \\
\text { foreign trade, } \\
\text { billion USD }\end{array}$ & $\begin{array}{c}\text { Russia's } \\
\text { share, \% }\end{array}$ & $\begin{array}{c}\text { Turkey's } \\
\text { share, \% }\end{array}$ \\
\hline $\mathbf{2 0 0 8}$ & 27.7 & 6.1 & 33.8 & 734.9 & 333.9 & 11.3 & 4.5 \\
\hline $\mathbf{2 0 1 0}$ & 20.3 & 4.9 & 25.2 & 625.9 & 299.4 & 8.7 & 4.0 \\
\hline $\mathbf{2 0 1 2}$ & 27.4 & 6.9 & 34.3 & 841.9 & 389.0 & 8.5 & 4.0 \\
\hline $\mathbf{2 0 1 6}$ & 13.4 & 2.1 & 15.5 & 460.5 & 341.1 & 5.0 & 3.3 \\
\hline $\mathbf{2 0 1 8}$ & 21.3 & 4.2 & 25.5 & 688.2 & 390.8 & 6.7 & 3.7 \\
\hline $\mathbf{2 0 1 9}$ & 21.0 & 4.9 & 26.0 & 267.2 & 374.3 & 7.2 & 9.7 \\
\hline
\end{tabular}

Source: calculated by: Trade between Russia and Turkey (2013-2019) // Ru-Stat. URL: https://en.ru-stat.com/dateY2013-2020/RU/trade/TR (accessed: 21.04.2020) and Foreign Trade Statistics // Turkish Statistical Institute. URL: https://biruni.tuik.gov.tr/disticaretapp/disticaret.zul?param $1=0 \&$ param $2=0 \&$ sitcrev $=0 \&$ isicrev $=0 \&$ sayac $=5801$ (accessed: 21.04.2020).

share is $2.6 \%{ }^{5}$. For Russia, Turkey is the second-largest importer of Russian gas after Germany. Moreover, for Turkey, Russia ranks third in the number of oil-exporting countries to Turkey after Iraq and Iran. In 2018, Turkey imported $46.9 \%$ of its natural gas consumption and $25.21 \%$ of its oil from Russia ${ }^{6}$. It also demonstrates that Turkey is still dependent on Russia for energy supply; it is the main pillar of trade volume of two states. Both countries intend to increase the volume of mutual trade to 100 billion USD (Masumova, 2018, p. 38). The table 1 shows the trade data of the two countries. Moreover, mutual investments between Russia and Turkey reach 20 billion USD. Turkish firms are also implemented in Russia at the 1972 project in the amount of 75.7 billion USD ${ }^{7}$.

Recently, military and technical cooperation has started to develop as a new area for bilateral relations. The most significant move in that area is Turkey's purchase of S-400 air defense systems from Russia. That has resulted in several problems within the alliance as a NATO. Turkey has been excluded from the F-35 program in

\footnotetext{
5 Экспорт из России в Турцию. «Нефть и нефтепродукты». 2013-2018 // Ru-Stat. URL: https://rustat.com/date-Y2013-2018/RU/export/TR/0527 (дата обращения: 02.05.2020).

${ }^{6}$ Enerji Piyasası Düzenleme Kurumu, Petrol Piyasası 2018 Sektör Raporu // EPDK. 30.11.2019. URL: https:/www.epdk.gov.tr/Detay/Icerik/3-0-104/petrolayliksektor-raporu (accessed: 21.05.2021).

${ }^{7}$ Türkiye-Rusya İlişkileri // T.C. Dış İşleri Bakanlığı. URL: https://www.mfa.gov.tr/turkiye-rusya-siyasi-iliskileri. tr.mfa (accessed: 15.04.2020).
}

return. Although the S-400 air defense systems are not currently activated in Turkey, this purchase is a significant illustration of changing Turkish foreign policy priorities. In Russia, such critical arms sales to a traditional Western ally will undoubtedly be considered to affect the NATO alliance. The example of cooperation with Turkey in the military-technical field offers also an alternative to the other Western allies.

Although the regional interests of Turkey and Russia are generally competitive, bilateral economic relations have developed successfully. As a result, Russian-Turkish relations have a structure that deepens from the energy field to military-technical partnership. In addition to Turkey's purpose of deepening its relations with Eurasian countries and Russia's foreign policy objective to maintain its status as a great power brings them a significant opportunity to develop bilateral relations.

\section{Russian-Israeli Relations}

After the reestablishment of diplomatic relations in 1991, the changing balances in domestic politics between pro-Western and antiWestern leads in Russia have brought ups and downs to the Russian-Israeli relations. Developing relations with Israel was not wellreceived by communists and ultranationalists, assuming Israel as a Western ally (Freedman, 1998). The Israeli direction of Soviet/Russian foreign policy has been mostly subjected to its relations with the West or its Middle Eastern policy, highly dependent on Russian-Western 
relations (Katz \& Casula, 2018, p. 295). Nevertheless, Russian-Israeli relations have become relatively stable and pragmatic in political, technical, economic, and cultural spheres for 30 years despite conflicting interests.

\section{Political, Economic and Military Relations}

The positions of the two countries in several international problems determine the limits of bilateral relations. Paving the way for reconstructing bilateral relations in the early 1990s, the Arab-Israeli peace process expanded Russian-Israeli communication. This enabled Russia, seeking to restore its great power role, to play an active role in the solution of Palestinian problem (Zvyagelskaya, 2014, p. 123). Russia, as the USSR did, acknowledges Israel's right to exist and security concerns, stands by the UN Resolutions, suggesting a two-state solution, is critical of Israeli occupation in the West Bank. So far, Russian foreign policy concepts have not addressed its relations with Israel; however, the Israeli-Palestinian conflict is mentioned as a critical issue. Russia is determined to seek resolution, underlining its great power role with permanent membership to UNSC and Middle East Quartet. During several international crises that engendered the Western-Russian confrontation, Israel dissociated from the West. One of the very first examples of it was when Israeli foreign minister Ariel Sharon criticized the NATO Operation to Kosovo. Israel did not join Western sanctions against Russia after the Ukrainian crisis, although it does not recognize Crimea as Russian territory. By doing so, Israel could avoid any threat of Russian arms-sales to its enemies in the region, as it happened during the conflict in the Caucasus (Pinfold \& Peters, 2021, p. 42).

After the Chechen Wars and terrorist attacks in Russia, when radical Islam and terrorism have become a security threat for the national security, Russia and Israel have had a common security concern, levelling the security aspect of the relations beyond great power competition in the Middle East ${ }^{8}$. Common terrorism threat opened

\footnotetext{
${ }^{8}$ Borshchevskaya A. The Maturing of Israeli-Russian Relations // The Washington Institute. April 15, 2016. URL: https://www.washingtoninstitute.org/policy-analysis/ maturing-israeli-russian-relations (accessed: 12.01.2021).
}

up one of the most vital bilateral cooperation areas. During a Middle East tour in 2004, Russian Foreign Minister Sergei Lavrov accepted cooperation in counter-terrorism with Israel (Freedman, 2010, p. 54).

In 2015, despite their contradictory concerns, Israel rapidly adjusted its policy to the conditions, changed with Russia's emergence in the region as an assertive great power, yet indicated its concerns over the Iranian penetration in Syria towards Israeli borders (Lasensky \& MichlinShapir, 2019, p. 142). Russia and Israel are aware of the consequences of trapping in a zero-sum game in Syria. Pragmatic and realistic policies sustained successful military-diplomatic coordination between Russian and Israeli officials to eliminate any confrontation risk. Such coordination prevented the Il-20 in 2018 incident from escalating into a confrontation despite the Russian accusations on Israel and increased antiIsraeli/Western rhetoric ${ }^{9}$. On the other hand, Russian President Putin was convinced about its tragic incidental circumstances, differing from the intentional downing of the Russian SU-24 jet by Turkey ${ }^{10}$. Besides, Netanyahu's efforts to maintain good relations have prevented alienation of parties.

Israel and Russia have deep historical, social, and cultural ties despite the short history of diplomatic relations. Nevertheless, this fact has been officially reflected more after the second term of Vladimir Putin's Presidency in 2004. Putin promotes the Russian-Israeli cultural ties, a shared Russian-Israeli identity through religion by underlining the importance of holy land for the Orthodox Russians, through history reviving the role of the Red Army in defeating

\footnotetext{
${ }^{9}$ See: МИД РФ вызвал посла Израиля в связи с ситуацией со сбитым в Сирии Ил-20 // ТАСС. 18.09.2018. URL: https://tass.ru/politika/5576477 (дата обращения: 12.01.2021); Глава комитета СФ считает, что инцидент с Ил-20 в Сирии срежиссирован Израилем // ТАСС. 18.09.2018. URL: https://tass.ru/politika/5577422 (дата обращения: 12.01.2021).

${ }^{10}$ Putin says loss of a Russian warplane to Syria's air defense during an Israeli attack was due to 'tragic accidental circumstance' // Meduza. September 18, 2018. URL: $\quad$ https://meduza.io/en/news/2018/09/18/moscowblames-israel-for-the-russian-military-plane-shot-down-insyria-by-syrian-air-defense (accessed: 12.01.2021).
} 
the Nazis and freeing the Jewish population from the concentration camps in World War II and the Soviet support and role in the foundation of Israel, and through language by emphasizing the Russian-speaking society of Israel, the largest Russian speaking community out of the former Soviet Union, consisting of around $12 \%$ of the Israeli population. Israel's Russian-speaking society is one of the most frequently mentioned phenomena as a potential source of Russian soft power in Israel. In his official speeches, Vladimir Putin often refers to Israel's Russian-speaking society, stressing the organic link between countries. Furthermore, many Russian-speaking Israelis have had important positions in government and representation in Knesset. However, it is still hard to find a prominent Russian lobby in Israel, pursuing particular relations with Russia (Moshkova, 2018, p. 391).

Despite the efforts made, there are significant obstacles to more institutionalized and stable bilateral relations. Kremlin's close relations with Iran, Syria, and Hamas, on the one hand, Israel's long-lasting partnership with the US on the other, remind the Cold-War-like alliances that are based on a zero-sum game. Arms sales are one of the critical issues within this context. Israel has long been concerned that Russian arms sales to its enemies like Syria and Iran would change the regional balance of power. Nevertheless, arms sales often have been considered as quid pro quo by both countries in bilateral relations. In the mid-2000s, Russia refused to sell Iskandar missiles to Syria due to Israeli concerns (Freedman, 2014). During the Russo-Georgian War in 2008, Israel could prevent the delivery of the S-300 air-defense system to Iran in exchange for halting its armssales and military assistance to Georgia (Pinfold \& Peters, 2021, p. 42)

Again, after the Il-20 incident, Russia began to deploy S-300 in Syria, delivery of which Netanyahu convinced Putin to cancel in $2013^{11}$. After the 2008 Georgia - South Ossetia War, the Russian development of unmanned aerial

${ }^{11}$ Friedman R. Russia Canceled S-300 Deal with Assad, Report Says // Times of Israel. May 26, 2013. URL: https://www.timesofisrael.com/russia-cancels-s-300-saleto-syria/ (accessed: 13.01.2021). vehicle (UAV) proved inefficient, and Israel has become the only Middle Eastern country that exports military equipment to Russia, while the region itself is one of the main destinations of Russian arms. According to SIPRI arms transfer database $^{12}$, Russia bought Forpost, to be produced in Russia, and Zastava UAVs from Israel between 2009 and 2010, expected to contribute to the modernization of the Russian military. Israel was interested in arms-sale to Russia, through which it can attain further influence in Russian foreign policy (Katz \& Bohbot, 2017, p. 199). Long delay of Russian S300 to Iran followed these deals, including close military cooperation and professional support to Russian personnel on $\mathrm{UAV}^{13}$. In 2014, against the backdrop of American pressure regarding the Ukrainian crisis, Israel suspended the cooperation with Russia ${ }^{14}$. Russian Minister of Defense announced modification of Forpost in 2017, which would be developed entirely based on Russian production ${ }^{15}$.

Israel is convinced that a stronger Iranian nuclear capacity is a direct threat to its security. Hence, the nuclear deal signed between Iran and Russia in 2005 is another notable matter for Russian-Israeli relations. Russian relations with Hamas and Russian stance towards Hezbollah's activities are other sources of the Israeli skepticism and increase tension between parties, highlighting Moscow and Israel's different positions. Besides, the depth of Israeli-American relations from military to diplomatic areas affects Russia's Israel policy. In contrast to Russian

${ }^{12}$ SIPRI Arms Transfers Database // SIPRI. March 15, 2021. URL: https://www.sipri.org/databases/armstransfers (accessed: 21.05.2021).

${ }^{13}$ Hilsman P. Analysis: Drone deals heighten military ties between Israel and Russia // Middle East Eye. October 4, 2015. URL: https://www.middleeasteye.net/ news/analysis-drone-deals-heighten-military-ties-betweenisrael-and-russia (accessed: 13.01.2021).

${ }^{14}$ Egozi A. Israel blocks further UAS sales to Russia // Flight Global. August 4, 2014. URL: https:/www.flightglobal.com/military-uavs/israel-blocksfurther-uas-sales-to-russia/114113.article (accessed: 13.01.2021).

${ }^{15}$ Новый военный беспилотник «Форпост-Р» начнет поступать в войска с 2020 года // TACC. 22.08.2019. URL: https://tass.ru/armiya-i-opk/6788812 (дата обращения: 13.01.2021). 
multilateral policy, cooperating with multiple actors, including Israeli enemies, the US foreign policy decisions in favor of Israel, such as moving the American Embassy to Jerusalem, recognition of Golan Heights as Israeli territory, restricts Russian political thinking concerning Israel.

Enhancement of economic relations and joint projects, especially in agriculture, high technology, and industry is supported by the both governments despite the negative effects of the political problems, different economic systems and geographical factors. Israel's good grasp of Western technology renders cooperation with Israel more substantial for Russia under the Western economic sanctions. Experts tend to see the combination of the relatively cheaper industry, the demand for high technology and inflow of capital in Russia, and Israel's development level in high-tech as an opportunity that can constitute a ground for cooperative projects in scientific and technological fields (Oulin, 2013, p. 81).

According to Russia's Federal Customs Service data, Israel was ranked 48, the lowest in comparison to earlier 10 years, among Russia's trade partners in 2019 and Russian-Israeli trade in 2019 amounted to 2250 million USD, $17 \%$ lower than 2018 trade volume ${ }^{16}$. Nevertheless, Russian Deputy Minister of Energy Anton Inyutsyn stated that "At the end of 2019, the trade turnover between Russia and Israel exceeded 5 billion USD, half of which was in the energy sector" ${ }^{\prime 17}$. The difference between the given numbers stems from the Israeli policy of not announcing its oil and gas purchase for security concerns. With the discovery of natural gas fields in its territories Israel appeared as a potential competitor of Russia in the European

\footnotetext{
16 Торговля между Россией и Израилем в 2020 году // Внешняя торговля России. 13.02.2021. URL: https://russian-trade.com/reports-and-reviews/2021-02/ torgovlya-mezhdu-rossiey-i-izrailem-v-2020-g/ (дата обращения: 30.05.2021).

${ }^{17}$ Антон Инюцын: «По итогам 2019 года товарооборот между Россией и Израилем превысил 5 млрд долларов, из которых половина пришлась на энергетический сектор» // Министерство энергетики Российской Федерации. 22.01.2020. URL: https://minenergo.gov.ru/ node/16847 (дата обращения: 13.01.2021).
}

market. Nevertheless, instead of competition, introduction of the experienced Russian companies, such as Gazprom, to the Israeli natural gas sector, through technology export bears many profits for Russia, which needs consolidating its influence in the region.

The visa-free agreement in 2008 between the countries drastically increased the number of Russian tourists to Israel and the number of Israelis visiting Russia, which could contribute to tourism and bring Russia investment from Israel. In 2019, Putin and Netanyahu decided to accelerate the creation of a free-trade zone between Israel and Eurasian Economic Union (EAEU). In March 2020 the 6th and last round of negotiations on a free trade agreement was held with Israel ${ }^{18}$. The deal has not been signed yet, although it was anticipated to be signed in early $2021^{19}$. Given the Israeli economy's size, a substantial economic contribution is not expected. However, if EAEU can make a deal with Israel while having the preferential trade agreement with Iran, it can advance the Russian great power image, based on its multidimensional foreign policy capability.

\section{Conclusion}

The great powerness is a significant component of Russian national identity and foreign policy discourse. The great power status of Russia, as a product of centuries-long Russian-Western relations, has also become one of the important determinants of the RussianWestern relations. It also allows the development of relations with regional states in the Western alliance. In this way, Russia strengthens its great power status in the international system while providing foreign policy alternatives in various

${ }^{18}$ Информация о ходе реализации в 2020 году государственной программы Российской Федерации «Развитие внешнеэкономической деятельности» // Министерство экономического развития Российской Федерации. 28.04.2021. URL: https://economy.gov.ru/material/ file/ef3a3c6e82ca59883d1e1c3002772600/otchet_2020.pdf (дата обращения: 30.05.2021).

${ }^{19}$ Израиль надеется подписать соглашение о ЗСТ с ЕАЭС в начале 2021 года // ТАСС. 02.12.2020. URL: https://tass.ru/ekonomika/10151795 (дата обращения: 14.01.2021). 
areas for regional powers in Western alliance such as Israel and Turkey.

Russia's belonging to and exclusion from the West have influenced the nature of relations. Notably after the Ukrainian crisis in 2014, the deteriorated Russian-Western relations underlined Russian exclusion from the West despite the earlier Russian efforts to integrate the country in the Western block. Accordingly, in the context of worsening relations with the West after that crises, Russia puts emphasize on nonWestern world, prioritizes its relations with China, a rising superpower endangering the U.S. global hegemony that can lead to the formation of a multipolar international system.

On the other hand, balanced RussianWestern relations are essential for securing its great power status and contributing to forming a multipolar world order. Despite the worsening relations with the West, Russia could maintain strategic and pragmatic relations with nonWestern allies of the West. Instead of costly direct normalization efforts towards the West, Russia pragmatically improves bilateral relations with Israel and Turkey, which are traditional Western allies. Russian-Turkish relations have developed deeper, particularly in the economic sphere, compared to Russian-Israeli relations due to political, economic, and geographical reasons. The purchase of Russian S-400 air defense systems initiated military and technical cooperation between the two countries, signaling a profound transformation in Turkish foreign policy. For its part, Israel constitutes a donor/supplier of high technology from military to agricultural spheres for Russia. Russia, in turn, offers Israel opportunities to influence its enemies in the region, which the U.S. lacks.

Both Turkey and Israel are critical regional powers and historical Western allies for Russia, seeking to fill the power vacuum, emerged out of reduced US interest in the Middle East. Russia's relations with Israel and Turkey are vital for its great power status, installed over its multidimensional dialogue capacity across the region. For Turkey and Israel, Russia is an alternative country for their foreign policy priorities in different fields from economy to military-technical cooperation. Developing bilateral or trilateral mechanisms, such as the Astana Peace process with Turkey and Iran or military coordination with Israel in Syria, Russia offers these non-Western allies alternative policy options beyond what the West suggests them. These relations, first, can be a domain for Russia to challenge the West beyond its immediate borders and achieve its recognition of Russian great power-ness. Second, Russia can decrease its alienation from the West, prevent further Chinese-American bi-polarization of the world order, and maintain its position as a great power with stronger influence.

Received / Поступила в редакцию: 18.01.2021 Accepted / Принята к публикации: 10.06.2021

\section{References / Библиографический список}

Buzan, B., \& Waever, O. (2004). Regions and powers: The structure of international security. Cambridge: Cambridge University Press.

Denisov, I., \& Safranchuk, I. (2016) Four problems of the SCO in connection with its enlargement. Russian Politics and Law, 54(5-6), 494-515. https://doi.org/10.1080/10611940.2016.1296304

Denisov, I., Kazantsev, A., Lukyanov, F., \& Safranchuk, I. (2019). Shifting strategic focus of BRICS and great power competition. Strategic Analysis, 43(6), 487-498. https://doi.org/10.1080/09700161.2019.1669888

Erşen, E. (2017). Evaluating the fighter jet crisis in Turkish-Russian relations. Insight Turkey, 19(4), 85-103. https://doi.org/10.25253/99.2017194.06

Freedman, R. O. (1998). Russia and Israel under Yeltsin. Israel Studies, 3(1), 140-169.

Freedman, R. O. (2010). Russia, Israel and the Arab-Israeli conflict: The Putin years. Middle East Policy, 17(3), 51-63. https://doi.org/10.1111/j.1475-4967.2010.00450.x

Freedman, R. O. (2014). Israel and Russia: Jerusalem and its relations with Moscow under Putin. In C. Shindler (Ed.), Israel and the world powers diplomatic alliances and international relations beyond the Middle East (pp. 125-154). London and New York: I.B. Tauris. 
Hopf, T. (2002). Social construction of foreign policy: Identities and foreign policies. Moscow, 1955 and 1999. Ithaca and London: Cornell University Press.

Katz, M. N., \& Casula, P. (2018). The Middle East. In A. P. Tsygankov (Ed.), Routledge handbook of Russian foreign policy (pp. 295-310). London and New York: Routledge.

Katz, Y., \& Bohbot, A. (2017). The Weapon wizards: How Israel became a high-tech military superpower. New York: St. Martin's Press.

Kuchins, A. C., \& Zevelev, I. A. (2012). Russian foreign policy: Continuity in change. The Washington Quarterly, 35(1), 147-161. https://doi.org/10.1080/0163660X.2012.642787

Lasensky, S. B., \& Michlin-Shapir, V. (2019). Avoiding zero-sum: Israel and Russia in an evolving Middle East. In K. Mezran \& A. Varvelli (Eds.), The MENA Region: A great power competition (pp. 141-157). Milano: ISPI and Atlantic Council.

Lukin, A. (2018). A Russian perspective on the Sino-Russian rapprochement. Asia Policy, 13(1), 19-25. https://doi.org/10.1353/asp.2018.0004

Masumova, N. (2018). Russia and Turkey: Resetting economic partnership. PERCEPTIONS: Journal of International Affairs, 23(2), 33-50.

Mearsheimer, J. J. (2001). The tragedy of great power politics. New York: W. W. Norton \& Company.

Moshkova, T. (2018). Russian-Israeli relations: The role of the Russian-speaking community of the state of Israel. Vestnik RUDN. International Relations, 18(2), 387-399. https://doi.org/10.22363/2313-0660-2018-182-387-399

Neumann, I. (2003). Russia and the idea of Europe: A study in identity and international relations. New York and London: Routledge.

Oulin, S. (2013). Bilateral Economic Relations. In Z. Magen \& V. Naumkin (Eds.), Russia and Israel in the changing Middle East (pp. 81-86). Tel Aviv: Institute for National Security Studies.

Pinfold, R. G., \& Peters, J. (2021). The limits of Israel's periphery doctrine: Lessons from the Caucasus and Central Asia. Mediterranean Politics, 26(1), 25 - 49. https://doi.org/10.1080/13629395.2019.1693125

Safranchuk, I. A. (2018). Russian-U.S. relations: Torn between the practical and ideational agendas. Russia in Global Affairs, 16(4), 96-119. https://doi.org/10.31278/1810-6374-2018-16-4-96-119

Safranchuk, I. A. (2020). M - Messianism. Russian in Global Affairs, 18(1), 105-107. https://doi.org/10.31278/ 1810-6374-2020-18-1-105-107

Shakleina, T. A. (2011). Great powers and regional subsystems. Mezhdunarodnye Processy, 9(2), 29 -39. (In Russian). [Шаклеина T.A. Великие державы и региональные подсистемы // Международные процессы. 2011. Т. 9. № 2. С. 29-39.]

Tsygankov, A. P. (2016). Russia's foreign policy: Change and continuity in national identity. New York: Rowman \& Littlefield.

Tsygankov, A. P. (2020). G - Great powerness. Russia in Global Affairs, 18(1), 85-91. https://doi.org/10.31278/ 1810-6374-2020-18-1-85-91

Ulçenko, N. (2016). Sovyet Sonrası Dönemde Türkiye-Rusya Ticari ve İktisadi İlişkileri. Marmara Türkiyat Araştırmaları Dergisi, 3(2), 121-138.

Zvyagelskaya, I. D. (2014). Middle East clinch: Conflicts in the Middle East and Russian politics. Moscow: Aspekt Press publ. (In Russian). [Звягельская И.Д. Ближневосточный клинч: конфликты на Ближнем Востоке и политика России. М.: Аспект Пресс, 2014.]

About the authors: Birinci Ebru - PhD Student, Department of Comparative Politics, Lomonosov Moscow State University; ORCID: 0000-0002-6919-4275; e-mail: ebrubirinci@windowslive.com

Sucu Ali Emre - PhD Student, Department of Global Political Process, MGIMO University; ORCID: 0000-0003-0789-2198; e-mail: a.sudju@inno.mgimo.ru

Safranchuk Ivan Alekseevich - PhD in Political Sciences, Director, Center of Euro-Asian Research, Institute for International Studies, MGIMO University; ORCID: 0000-0003-2214-6628; e-mail: i.safranchuk@inno.mgimo.ru

Сведения об авторах: Биринчи Эбру - аспирантка кафедры сравнительной политологии Московского государственного университета им. М.В. Ломоносова; ORCID: 0000-0002-6919-4275; e-mail: ebrubirinci@windowslive.com

Суджу Али Эмре - аспирант кафедры мировых политических процессов МГИМО Университета; ORCID: 0000-0003-0789-2198; e-mail: a.sudju@inno.mgimo.ru

Сафранчук Иван Алексеевич - кандидат политических наук, директор Центра евроазиатских исследований Института международных исследований МГИМО МИД России; ORCID: 0000-0003-2214-6628; e-mail: i.safranchuk@inno.mgimo.ru 